Relations industrielles

Industrial Relations

\title{
Trade Unions in Canada: 1812-1902, by Eugene Forsey, Toronto, University of Toronto Press, 1982, 600 p., ISBN 0-8020-6388-8.
}

\section{James Thwaites}

Volume 38, numéro 1, 1983

URI : https://id.erudit.org/iderudit/029337ar

DOI : https://doi.org/10.7202/029337ar

Aller au sommaire du numéro

Éditeur(s)

Département des relations industrielles de l'Université Laval

ISSN

0034-379X (imprimé)

1703-8138 (numérique)

Découvrir la revue

Citer ce compte rendu

Thwaites, J. (1983). Compte rendu de [Trade Unions in Canada: 1812-1902, by Eugene Forsey, Toronto, University of Toronto Press, 1982, 600 p., ISBN 0-8020-6388-8.] Relations industrielles / Industrial Relations, 38(1), 179-180. https://doi.org/10.7202/029337ar

Tous droits réservés (C) Département des relations industrielles de l'Université Laval, 1983
Ce document est protégé par la loi sur le droit d'auteur. L'utilisation des services d'Érudit (y compris la reproduction) est assujettie à sa politique d'utilisation que vous pouvez consulter en ligne.

https://apropos.erudit.org/fr/usagers/politique-dutilisation/ 
Trade Unions in Canada: 1812-1902, by Eugene Forsey, Toronto, University of Toronto Press, 1982, 600 p., ISBN 0-8020-6388-8.

Senator Eugene A. Forsey set himself a very ambitious task in trying to put together an overview of the first half of Canada's labour history in a single volume. The result is a hefty 600-page work covering the years 1812-1902 in almost incredible detail and truly pan-Canadian scope.

Of course, the CLC's original centenial objective for this project, as proposed to then research director Forsey, was more ambitious still: to cover it all from earliest beginnings to 1967. And one can imagine what that would have looked like as well as the time it would have taken. (Incidentally, the author did compile notes for the sequel and they have apparently been deposited at the Public Archives of Canada.)

Today's social scientists and administration specialists, used to more accessible information, would be astounded by the sheer difficulty of sticking together the pieces of such an enormous, inevitably incomplete jigsaw puzzle. The author's method thus resembles more that of a statistician wrestling with imperfect sources than that of the probability theorist.

As Forsey tells us at the outset, the gaps were of two sorts: incomplete and spotty original documents, as well as few in-depth authoritative interpretations (IX)' In the face of such problems, the author chose to present "few opinions or arguments ... few analyses" (X). The book in his eyes, therefore, was: "an attempt to fill in the factual gaps in our knowledge of early unionism" (X). In this, however, he was too modest for more analysis and argument would have been important.

According to the objective established, the author has certainly succeeded for what he has presented us with is a wealth of pertinent details, statistics and fascinating vignettes of unions and thier activities during the period. He structured them in four major sections: Early unionism: 1812-1880; International unions: 1880-1902; Local, regional, and national unions: $1880-1902$ and Central organizations: 1880-1902. The vignettes presented are probably the result of certain concentrations of primary documentation and interpretations. They include for example: the intense, widely-organized labour scene in Saint-John, New Brunwick, at the beginning of the 19th century (9ff); Médéric Lanctôt's efforts in the province-wide ambitions of his Grand Association (81ff); the struggles of the Ship Labourers' Benevolent Society to maintain its position in the midcentury port of Québec City (304 ff); the fascinating development of Canada's first Ontario-based national labour central, the CLU, (119 ff) and Canada's version of the gun-fight at the O.K. Corral, better known as Mgr. Taschereau $v s$ the Knights of Labour (141 ff). The chapters of section four, on Central Organizations, are more easily assimilated than the others perhaps because of their generally more unified themes, and doubtless more abundant and consistant information available.

Reflecting on the other than intrinsic interest in the subjects covered in his book, Forsey remarks:

"What does emerge, unmistakably, and most surprizingly is the persistence of problems, of attitudes towards them, of methods of dealing with them, of arguments about them. ... what one finds is, over and over again, startlingly contemporary. ..... The unions were so often fighting for the same things they are fighting for now, wielding the same weapons, using the same arguments; employers were so often resisting exactly the same things, wielding the same weapons, using the same arguments. Governments were so often acting, or not acting, for precisely the same reasons, or lack of reasons, as now.» (5)

This is not the sort of book you curl up with on a cold winter's evening and read straight through. It is a book with a wealth of 
information, to be consulted frequently on its various facts and themes. In other words, the author has provided us with a veritable encyclopedia regarding the first century of Canada's labour history, which no serious labour specialist can afford to neglect.

James THWAITES

Université Laval

A Primer on American Labor Law, by W.B. Gould, Cambridge, Mass., The MIT Press, 1982, 242 pp., ISBN 0-262-070 87-1.

Voilà un ouvrage relativement bref dont la parution comble une lacune aussi étonnante que manifeste: l'absence relative de synthèses véritables du droit du travail américain, vaste domaine quasi monopolisé par des études dont la technicité rend plutôt difficile au lecteur - à tout le moins le lecteur étranger - d'appréhender les données essentielles du système en cause. Le professeur Gould, de Stanford University, réalise au surplus son entreprise en se permettant à l'occasion des rapprochements particuliers avec quelques systèmes étrangers - notamment ceux d'Angleterre, d'Allemagne, de Suède et du Japon -, ce qui est également peu fréquent dans les présentations connues du sujet.

La quasi-totalité des douze chapitres sont consacrés au droit de la négociation collective, ce qui reproduit assez fidèlement l'atrophie systémique des rapports collectifs du travail. Cet ensemble central est lui-même précédé d'une brève mise en contexte en fonction essentiellement des structures et des attitudes syndicales américaines et, surtout, d'une substantielle fresque de la période préWagner Act: histoire des tentatives répétées du travail organisé d'utiliser sa force politique pour contrer des attitudes jurisprudentielles défavorables et dont le dernier succès sera l'adoption du Norris-La Guardia Act, qui se rattache encore à une ère proprement libérale: "Norris-La Guardia was a laissezfaire approach to industrial relations, a strongly worded series of instructions to the federal courts to keep their hands off labour disputes because they had made a mess of things by intervening in the past"' (p. 27).

L'étude du système mis en place par le National Labor Relations Act de 1935 porte principalement sur la désignation des représentants collectifs, l'objet des différentes pratiques déloyales en matière de représentation et de négociation collective, la licéité du recours à différents moyens de pression surtout dans le cours d'une négociation collective, de même que sur le rôle privilégié de l'arbitrage prévu dans la convention collective. Dans ces pages, l'auteur décrit fort utilement les modes de fonctionnement du National Labor Relations Board et fait état également des principales prises de position des hautes juridictions fédérales. Le droit devient prétorien, comme lorsqu'il s'agit de jauger les comportements dans le cours de la négociation collective, ou encore l'objet obligatoire ou facultatif de cette dernière, le droit d'accès des représentants syndicaux aux lieux du travail, les limites du "free speech" des protagonistes, ou encore celles des pressions exercées sur des tiers ... L'auteur s'interroge aussi sur certains aspects de l'efficacité de fonctionnement du Board et des tribunaux d'arbitrage. Enfin, l'étude du droit des rapports collectifs se complète par celle du sort du salarié, dans ce contexte primauté de l'intérêt du groupe: les balises du devoir de représentation équitable, qu incombe aux représentants collectifs, et aussi, les devoirs du syndicat envers ses membres, selon le Landrum-Griffin Act. On présente finalement l'essentiel de la problèmatique du recours à la grève dans les services publics.

Le dernier chapitre s'intitule: "PublicInterest Labor Law". Il s'agit d'un résumé du Employee Retirement Income Security Act et du Occupational Safety and Health Act de 1970, ainsi que de l'importante législation contre la discrimination dans l'emploi. Pour l'auteur, ces sujets représentent "the new frontier of labour law" (p. 194). Certes, jusqu'à présent, le droit du travail américain misant essentiellement sur la négociation collective, aussi dynamique que conflictuelle, a 